\title{
Like a Bridge over Troubled Waters: the Death of the Mother a Comparative Study in Literature Between USA and French Feminist Poetry
}

\author{
Eleni Karasavvidou
}

$\mathrm{PhD}$ in Intercultural Literature, Aristotle University of Thessaloniki

\begin{abstract}
The power of fear and the need for happiness are equal, wrote Adorno in Minima Moralia (2001, p. 223) describing in a phrase the inevitable contradictions of the human condition. Mother and motherhood reflect both, fear and need, transforming eachother in a constant dialogue that mediates the various expressions of our sociopsychological transformations. A dialogue unready to be completed as long as our worldviews sustain hierarchies that manipulate the need and the fear.
\end{abstract}

Keywords: Like a Bridge over Troubled Waters the Death of the Mother a Comparative Study in Literature Between USA and French Feminist Poetry

\section{Introduction}

"It is always the unreadable that occurs"

O. Wilde

"Fear" and "Need"...In the ethics of psychoanalysis Radcliff Brown pointed that ancient rituals survive in modern societies because they are essential part of the mechanism through which societies maintain their existence, promoting the establishment of certain fundamental social values (p. 951-959).

Yet, if the "round ground" of the ancient tribe has been transformed into the medieval square, and if the medieval square has been transformed into the front page or the screen of the media, the power of those ritualistic representations still functions.

Part of this broad process, literature is not actually a mirror. It mediates and represents social relations in schema of signs which require a receptive and preconditioned reader in order to be meaningful. And it is at the level of what those signs connote, often unconsciously, that ideologies are reproduced (Parker \& Pollock 1981: 119). The representations of mother and childhood connote signs and they reproduce ideologies. Yet, having also deep biological parameters, not only they are more easily manipulated in the social context, but they are also fundamental in the formation and articulation of "personal worlds". The Death of a Mother is always indeed extremely personal for a child and vise versa. To elaborate those "deaths" in literature is to elaborate a deep "border", a frontier between what is self interpretation and what is hetero-interpretation. Foucault's "panoptikon" could never find a better symbol than the internalized eye of the mother. Yet it is a mother that as Irigaray (1985) claims has been colonized by the hegemonic view of the maleworld. Texts that represent the mothers are produced in these particular cultures and societies and in particular historical circumstances. In turn, they shape and are shaped by those cultures as they are read and re-read in changing circumstances by different groups, with different commitments, engagements and interests. Such readings are themselves then re-absorbed into the ideological frameworks within which the cultures and persons develop.

Having said that it is obvious that any interdisciplinary approach should take into consideration time and space not just as the broader framework that influences literature, but as inevitable part of the texts themselves.

In a situation where "hierarchy becomes a natural order» (Fairclough, 1992), what appears to survive as a prime symbol from the collective cultural capital, acts not just as "an intermediator because its inherent significance determines the values of the present" (Pollock 1999: 10) but also as a factor, as "a writer within the writer", producing texts that are influenced always by .the personal characteristics of their carrier. And mother as a social symbol that becomes a multiple 
literary expression, is a case like that. We tent to believe that this operation depends its personal involvement on the significance of the archetypes it involves. We could argue that the most fundamental the archetype the less space exist for personal variation.

Mother and Motherhood are fundamental archetypes.(Campell,1980) And yet they had to be reread and reabsorbed in a decade of a massive transformation like the 60's. It was then (even as a brief break) that the average social subject of the "west" (schematically speaking) had to leave behind commonsensicals in everyday behavior, sociopolitical ideas and long term cultural and financial practices. But the western subject by doing that, by leaving what was well known and established, became "an immigrant within" in a "terra nova". And an essential part of migration experience is notion of nostalgia for the roots, roots represented by a symbol like mother.

In this framework, the traditional discipline of literary history has to be expanded and challenged by new insights and by alternative perspectives. Exploring the evolution in the so called "eternal entities" like the one we try to challenge here. Was mother a bridge over troubled waters, or she became the troubled waters herself? But then who became the bridge? Was that a part of a Spinosian causa sui project? A part of an effort, in other words, to make the world "our own case", in a constant effort to become parents of ourselves? This might be an ultimate human desire and according to Brenkman (1982) the contradiction between Platonic and Freudian theories in relation to Desire is the manipulation of Desire, as psychoanalysis argues that to elevate ourselves to the philosophical scale we should transcend not the body but mother's body.

But body means politics. And male colonization might means inner femo-phobia (in analogy to homo-phobia) Page du Bois $(1988,16)$ in Sowing the Body accuses Plato and Foucault for establishing the male subject as the ultimate master in philosophical perspective. "I homme de desir", destroying the analogic thought in the benefit of hierarchical thought.

Where is the woman "de desir?" If the totalitarian identification of female sexuality with reproduction meant her absolute identification with motherhood (Stehle, 1990, p. 96) then the complexity of female (and male) existence is "covered". And cover means "cover up". Seduction. And is this kind of seduction that, according to Baudrillard, (1990) "women exercise from a distance". The absence of women manipulates not just themselves but males too. Distance might means distance from ourselves.

Yet, in Greece the folk culture uses to call mother "the golden mattress" that have the capacity to "cover" all our falses, all our juxtapositions. Yet there is darkness wherever there is light: "Listen Kinnell, that throw you to be alive and half dead in a baby-bed! "There is only a mattress of fallen wings between you and the long abyss, an abyss so similar to you"... wrote Kinnell in the 60's1. May the journey begin in those rocky waters...

\section{The topic: Death}

"But Death, be not proud!", wrote Donne in his $5^{\text {th }}$ of the Divine Sonnets, articulating in an extraordinary way not a metaphysical but a "human-centered" comfort in front of this devastating phenomenon. A comfort deriving from the decent battle we fight in life and not from a post mortal religious solution. Yet, among the most frequently treated subjects in literature, death — present as a theme, symbol, or plot device - exists as one of the defining elements in the writing of modern poets, dramatists, and novelists. Intertwined with the origins of literature itself, human consciousness of mortality has for centuries provided the impetus for reflection on the causes, meaning, and nature of existence. And, while treatments of death are as varied as the authors who write them, scholars have perceived in modern texts - whether for the stage, in verse, or in prose fiction - certain clearly defined approaches to this topic of nearly universal interest: Acting as the ultimate existential dilemma, one which arouses terrible anxiety as it offers the rocky path toward authentic self-discovery, or often perceived within a larger context, as part of the natural cycle of decay and renewal, or treated as a source of laughter in black comedy and absurdist drama, who constitute a reverse recognition the high seriousness of their subject. Death in literature carries with it a range of symbolic implications, connoting the very sources of meaning and the creation of literature itself.

But what happens when death is linked with the fundamental personal figure that "created" us and gave us our first notion of meaning, mother? What happens when this is not always a natural death but it can be a moral or a symbolic one? "As we prepare to enter a new millennium it is clear that our concept of the mother is being radically destabilised and

1 Contemporary American poetry, trans. . K. Aggelaki Rourk, Athens 1985 
transformed" wrote Nancy Lane in The Mother in/and French Literature (p.x, introduction). What if it is linked not only with child experiences but also with mothers'? "Have you ever noticed that you get stronger feelings about death in a novel when it is the death of one of the major characters, rather than the minor ones?" Skelton (2003) sits the question. ...Do you feel differently when a morally "good" character dies than you do when a morally "evil" character does? And if that is so where most of the literary mothers that evolve in our selected case studies, belong? And is our preview about mothers free of imposed expectations? Our perspectives are truly liberated from a socio-psychological "guilt taboo" societies address to women? And is it common in both shores of the so-called west, France and USA?

\section{USA and France: Crossing Ocean's rocky waters}

This paper will concentrate on the female production of USA in comparison to the French Culture. Not only Nuevelle Sociologic interacted and integrated in famine escritoire, a vast topic in its own. But also because underneath any feminine perspective exist a French influence. "Possibly there is no other country the recent centuries having that kind of variety and significance in leading female figures: Queens, philosophers, writers, "priests", wrote Peyre (1979).

Also because American 60 s and French 60 s have considerable things in common. As it is referred "the history of French Literature is closely linked to the state of French Politics, ideology, and culture, often reflecting and shaping these realities in France. If that is so then we could claim that what happened to the States in the 60's was a "French-isation" as politics Ideology and Language became central to the American alternative thought. As it was written "while the idea of the French Resistance remained an integral part of French popular literature well into the 60s several writers began to question the myth of French unity ... and offered an alternative, disillusioned view of the bond forged during the war". Similarly while the idea of "the land of freedom" remained an integral part of American popular literature, several writers begun to question its myth and offered a less narcisistic version mostly in the 60's. Thirdly because of the vast analogies produced. If the States were rapidly radicalized because of Vietnam, (a link with France...) financial evolutions and cultural changes (that gave voice to the 'New Social Movements') the 60's was a turbulent time also for France. Despite "les trente glorieuses" in economy the country was torn by its colonial heritage (Vietnam, Indochina Algeria), and by its Vichy Regime, facing a collective guilt that gave also birth to "Nouveau" social Movements and Artistic expressions. Those expressions brought in the front line feminine writers, such as Marguerite Duras, Nathalie Sarraute, Anne-Marie Albiach, Julia Kristeva etc. The analogies between American language poetry movement (representatives of which we present in the following pages) and French Avant Garde (many around L'Ephemere) are profound. Equally profound is the marginalization of female writers in both countries.

Indeed a major trend in the critical study of modern French literature has been the marginalization of women authors. The period that this question evolved in both countries is not accidental. Discussing the role of women in authoritarian ideology and psychology as well as in the history of fascists movements parties and regimes, Melanie Hawthorne and Richard Golsan, suggest that male sexuality and misogyny from crucial building blocks of the fascist male psyche that dominated France through the early $20^{\text {th }}$ century, shutting out the feminine perspective in both political and intellectual arenas. Women could only be adored if she was $L$ Inconnue de la Siene1, beautiful, silent and dead. This sociopathology was not irrelevant with dominant perception of women. In many cultures women have been long suspected as the source of human miseries, especially in conservative and repressing times. Since the ancient myths women were idealized but mostly mistrusted as seductive and vengeful, manipulative and even malevolent. In modern times, as ideals of purity and dedication to family have been exalted and feminine beauty lauded, women have been viewed as embodying sinister forces of evil.

But this sociopathology was to be radicalised and politicised when the traditional role of motherhood was questioned. In traditional texts the narrative constructs of legitimacy functioned to marginalize women, in fact mothers, as this was the only way they could be seen. Mothers were not personalities but figures through which the fundamental needs for security and adorship of the son and related concepts of authority and authenticity were naturalized. But this figure of the ultimate sacrifice was not just a choice of personal downfall, but also became an alternative narrative authority, spreading a guilt not just in pages but in life also. The "distant seduction" of the women...

\footnotetext{
1 According to a famous story the body of a young woman was pulled out of the Seine River in Paris in late 1880. Enchanted by her beaty the pathologist of the morgue had a moulder make a plaster cast death mask of her face. This death mask that was reproduced influenced from the appearance of women to pages of American and European literature. In the 60 s it was reproduced by photographer Man Ray (possibly like pop art not in style but in concept) to denounce the marketable death icon of women.
} 
"But she was of the world where the most beautiful things have the worst fate" as Mlherbe wrote in the 50 's, having as an exception Highsmith's "Prize of Salt" (later renamed Carol). But in the 60s mostly a major redefinition happened. Questioning authority meant questioning macho psyche. Figures like De Beauvoir and Sarraute challenged the state and the ethics by revealing the hidden antagonism between mothers and children. This was not a new idea. Mile de la Force statement that "there is no bigger threat to the unborn child than mother herself, documented the degree on which early modern medical practice and popular belief valued the well being of the fetus over than of the mother. But female figures like De Beauvoir in France make a public statement urging the Frenh Democrary to jail the for having an abortion. In grappling with our understanding of what it is to be 'evil' (and thus marginalised) in changing eras, and how women are used to confront or identify with it, the paper aims to shine a spotlight on this dark area of the social and human condition through some significant texts and explore, without constructing of course permanent conclusions in that diversified issue, the possible sources of connection, of worship or of fear and resentment for women, death and motherhood.

Reproduction might be the exact opposite of motherhood. As Irrigaray claimed to resurrect the mother we need to acknowledge that she is not an empty space or filter for reproduction. (Lane, 2000, p.xv) On the contrary with Malherbe's poem, beatifull things could demand a better fate. The maternal metaphor was transfereed to society to become metonymy and history.

\section{The Sociology of the 60's.}

The growing search and academic literature related to social representations and archetypes the last decades made us realize "that every culture develops its own view of archetypal nature and within it a related set of beliefs» (Schwartzman, 1979) about the interactions of that nature with the rest of the culture. Representations and archetypes are made up of the expectations, hopes and fears societies have expressed with regard to their future as Sommerville (1982) put it. Those fears and expectations that shape symbols, never universally accepted, are formed within a pre-established but tacit ontological theory (Jenks,1996,p.4) that articulated the Self confronting the being of the "other" within the boundaries of hegemonic theories.

Child for instance, having been charged, in modernity, with all the miscellaneous societal and metaphysical notions that contribute to «the manifestations of the Other which so powerfully shape the narrative of the Self» (Cox,1996,p.127), was hired to promote a new kind of world view, a new kind of world order. A socially mother-oriented child in a patriarchic world was little by little evolved into a motherless child in an orphan world. As the radical doubt of Postmodernity (Lyotard, 1984) occurred and "seed" itself in the 60's, legislators of any kind (Bauman,1994) faced an elimination of their absolute necessity. The growth of sub-cultures and social movements, and yet also the growth of communication industries «intermediating between social groups and diverse meaning systems», erased the traditional ways of a commonsensical socialisation and exposed us in a chaotic world less powerful to shape or impose certain, monocultural identities and control, or in fact let others to control, our fate.

In the 60's, under the influence of radical social theories and movements like radical feminism, we glimpsed the complexity of social phenomena, and we tried «to redefine power» away from the state and the socio-economic elite. And re-establish it , under the influence of such political philosophers as Foucault, right into the hart of «the cultural and institutional formations of modern societies»(Cox, 1996,p.5) and «on the complex network of micro-powers»... «that permeate every aspect of social life».

But questioning the macrostructure of sociology allowed us to realise that «the major orienting concepts» (Schwartzman, 1979, p.10), such as childhood or motherhood, are not underlie into the naturalization realm, aiming «to process the child as a uniform entity» completed in a "firmly established, rational white male adult world» which is assumed to be homogenous «and most significantly desirable»(Jenks,1996, p.9). But, on the contrary, they might be «relative to temporal or historical circumstances», and power relations, «as well as sociocultural context» (Schwartzman1979, p.10).

In this context we learned to include our female selves through our exclusion. The groups that offered socialisation to us so many centuries, they were functioning as a Womb. A womb able to offer a symbolic death to us, until 60 's came. The era we tried to give birth to ourselves, schematically speaking, in a multiple diversified process, establishing our own semiology for our own, creating our symbolic lives.

Yet there was a Kyrke, able to trap us in her island: In a stable, manipulative process, having consumption -and not creation or political consciousness- as the tie between individual and society. But in this world of consumption were almost 
everybody could achieve 5 minutes of fame, were femininity, what ever that means in a certain framework, could be exposed and consumed in a chaotic space, to "be a woman" could easily end up as a Foucaultian "unheimlich", where the average social subject ends up carrying a "foreign public name", unable to identify it with herself in a personal level, like a celebrity, unfamiliar and distant to its own self.

This was not actually unexpected. Motherhood used to function since industrialisation as a social role projected an asset to accept more easily the atrocities of everyday life, in a deep negotiation process that intermediates society:

The rising nation states, in their effort to justify and take more power than ever before hiding social dispositions and their causes, (Stone,1982) used woman's and child's domesticated or successfully institutionalised image to impose social harmony.

Every religion has its temple. For the newly born bourgeois world this became the garden,(Grylls,1978), «enclosing within the safety of its walls a way in touch with nature and which preserved the virtues of earlier periods of the history of mankind» (Cunningham,1991). While adult society seemed «the more bleak, urbanised and alienated»,garden ,the «must» of bourgeois domestic ideal, full of biblical notions, became "the lost Paradise of childhood», "a place to nurture and express innocence»(Cox,1996,p.113). A market oriented archetype that was going to survive until the mid $20^{\text {th }}$ century.

This garden had to be preserved from the fruit of knowledge of evil: sex, in a western discourse aimed «to transform desire into religious ecstasy and perhaps even into rational endeavour» (Foucault, 1984, also Cox,1996, p.75). Social purity movement(Cox,1996,p.128), aimed to create a moral panic (Hall, 1982), «asserting the right to regulate the behaviour... in the interests of a particular ideology» (Cox, 1996, p.152) were still very powerful in the 50s.

It was within this new discourse seeking justifications for the withdrawal of the previously active female and child population from socio-economic mainstream, (through the intensive mother-child relation, and the growing maternal power as the sole arbiter of domestic morality), were Romanticism, like all the dreams hidden under its name, «was safely incorporated into a bourgeois definition of family life and its radicalness defused» (Cox,1996, p.115). Now the child was not the father of the man anymore. Blasted from a religious violence, hired to justify the new order, has become just «the father of the woman» (doctor G. Napheys, quoted in Cox,1996, p.139). There was no way to be a woman if not being a mother...

There were forces behind this campaign as Gorham (1978) argued talking initially about Victorianism: Bourgeois perceptions of domesticity and female passivity (Foucault,1984,also Cox,1996,p.151) aimed not only to control the sexuality of the growing child and to «scope limitations to childhood»(Cox,1996) but through the pure image of the young girl (De Mause, 1976, Kincaid, 1995 and Cox,1996) to ignore the realities of working class life in the beginning.

Or, we could add, to ignore the atrocities of wars miles away from home even decades later: "We are America, We are those who made funeral coffins to be filled... the bomb explodes like a box of shoes. And the child? The child is not sleepy of course. And the Woman? The Woman washes her heart. It was ripped out as it was burnt and as an act of Telos she washes her heart into the River. This is the bargain of Death. America, where are your excuses?" wrote Ann Sexton in the 60s, confronting all that. The poetess employs a child and a woman, she might be a mother, drawing them outside from the everyday American neighbourhood, using both (child and woman) to articulate an exilic identity, whom in a process were orientalism (Said, 1979) will arise as the opposite pole, will confront our Western conceptions and perspectives.

Interestingly, what Sexton does is to play "naturalisation" in its own field. In the America she grew up «home, ruled by the father and kept clean by the mother, was to project the totality of the social existence were patriarchy was the legal code» (Kline,1993, p.57, quoting Ewen,1976).There is no father in the poem. There is no man. Only a woman and a child in a natural landscape, escaping domesticity, in fact confronting it as one source of their miseries... And yet, she, being a political subject, and yet also a woman and a mother, creates a poetry that could act as their voice too. In speculum of the other Woman Iragaray speaks about that double function of the woman being the object and the subject of her creative force, in an effort to intervene in her colonisation, but an effort were the hegemonic view has been internalised and reproduced. Women claim to re-birth a language and when Sexton stands in a distance from phallic America (where are your excuses, not our excuses) connects herself with what Kristeva in Women's Time (1981, p. 13-15) refers as the urge not to articulate a symbolic expression, a symbolic order of representation. Sexton distance her female self from "the peculiar, strange male violence were having to dare man obligatorily will reach evil and wonder, and were language speaks as a violent gathering, as manipulation of the mighty (Heidegger, 1959, 78) 


\section{Poetry}

Sixties altered a tremendous change in western life style in general. Yet a major center of this change was America. If death is the ultimate symbol of the 2 Ps, meaning Pain and Past, until then America had no sorrows, had no way to deal with. As Wecter wrote, one major cause for the incompleteness of the American myth is the lack of history. That gave a very special sense of belonging and a very special sense of travelling. One major strain of the American tradition sees life and history as just beginning... R.W.B. Lewis (1955, p.208) observes in his American Adam, that is an Adam before the fall, standing always in the threshold of the experience having no heavy baggages to burden his quest. This view of the innocent American hero is best represented in the works of Thoreau, Emerson, and Whitman (Rank, 1959). Heroes in their own works, their quests took them into garden-like places where they sought to preserve the vision of America's and new world's destiny.

But in the 60s time and space, Vietnam war and family crisis and capitalism, brought an end to the vision of innocence and newness. America moving to reality, and conflict inevitably arose at the point where Life and Death collided. To loose her virginity it was like to loose her vitality. America itself became a dying mother. Yet, there was a Grief Taboo as Boker explains (1997). In fact "despite the fundamentally tragic nature of the experiences of rebellion, separation, and loss out of which the' American Adam, like the American colonies themselves, was engendered, the themes of uncompromising selfreliance and a willfully chosen orphan identity have been viewed by a certain masculine critical perspective as celebrated events that, for the most part, were devoid of emotional consequences". Boker's mission in The Grief Taboo is to expose and explore precisely these emotional consequences. Behind the American Adam, Boker finds a legacy of mother-loss, father-hunger, repressed grief, repressed femininity, and persistent adolescent idealism that helped to create some of America's greatest fiction, but at a very real emotional and psychological cost.

Yet the female literature of the 60's helped to move away from that masculinity. In fact, promoting personal and political like an entity, shaked like never before the "Grief Taboo". Plath writes the aggressive 'Lady Lazarus' and the notorious 'Daddy', in which the poetess "expanded the boundaries intimate expression": Every woman adores a Fascist, /The boot in the face, the brute /Brute heart of a brute like you. (from 'Daddy', 1966)

Both Plath and Sexton are considered as representatives of the so called confessional poetry, along with Robert Lowell and John Berryman.Despite the significant male presences confession is considered a female attitude. In fact "Plath has been considered a deeply honest writer, whose ceaseless self-scrutiny has given a unique point of view to psychological disorder and to the theme of the feminist-martyr in a patriarchal society". For several of these writers, notably Plath and Sexton, death as a pretext for understanding life is of tantamount importance. In the poetry of these introspective writers, mortality exists as the defining sensibility, and is deeply rooted in a personal experience of the anguish of living and of death; an experience so intense for Plath and Sexton as to have culminated in their own suicides.

Yet, "DEATH be not proud,/ though some have called thee/ Mighty and dreadful, for, thou art not so,/ For, those, whom thou think'st,/ thou dost overthrow,/Die not, poore death,/ nor yet canst thou kill me." John Donne wrote, celebrating death-suffering as an inevitable part of all lives, within which lies also a feeling of eagerness, of an absolute passion for life. And how else could it be? We know Death will win, but Death need not be proud. Man fights a valiant fight; and, along the way, we gain our self-respect and the respect of others.

But Donne's era was a bit different than the 60's. Donne's era was romantic and yet, or due to that, was extremely optimistic in a deeper way of adulthood. Humanity had an endeavor in front to "taste" But 60s were "so young", and there was a certain amount of impetuous naivety mingled with an absolute realism. "Where are our excuses?" still Sexton's voice demands. "And what exists behind?/ Behind exists the emptiness. I And who is now speaking? Someone who sleeps under a hat./ And when he wakes up? He will go to the barber shop. They are going to shave his bier, his noise, his ears and his hair there. In order not to differ..." (Simic Charles, in Aggelaki, 1985, p.73)

Simic describes in a way the fate of his entire generation. Similar to Romanticism, the brave spirit of the 60s, a spirit were the journey was led by the possibility and not the map, «was safely incorporated into a bourgeois definition of family life and its radicalness defused» (Cox, 1996, p.115). "I have no idea who we thought we were/ that our personalities could survive/ the defeats of the clan/ For good or bad, we didn't know/ that the clan had defeats like that/ and that we were going to have our share..." wrote Adrienne Rich.... "Next year will be 20 years since you so prodigal died/ you that we thought you could make the jump we were talking about. Its rather late now to happen./ and now I 
survive not like an alter, but like a series of brief, rigorous moves/ each one of which gives to the following the right to happen".

If we think about it Rich speaks of an absolute perish of joy. Life, in this poem, is a mechanical process. It is not the honorable death that Donne describes. She speaks about humble people that despite they had dreams made of skies they had wings made from dust. She mourns humanity in her own words and through her personal loss. This kind of humble mourn is not easily connected with "soldiers" trying to escape real life searching for Camelot. The task is absent, the pain is present. Or the pain, a psycho-political pain in a violently politicizing society in that era, becomes the task?

Fate gave the word, the arrow sped/And pierc'd my darling's heart;/And with him all the joys are fled /Life can to me impart./By cruel hands the sapling drops, In dust dishonour'd laid:/ So fell the pride of all my hopes, /My age's future shade." Wrote Burns in a Mother's Lament a century before 60's. Rich's mourn seems like a feminine mourn, and provocatively speaking, every feminine mourn is a mourn of a mother.

Yet, "I am not your mother more than a cloud is/that drops into mirror to reflect in the moon its own, slow extermination from the hand of the wind... I wake up to hear: A distant sea moves inside my ear. A voice. And unstably I wake up from the bed" wrote Plath, expressing the hidden crevices inside that lies beneath gender oriented motherhood. And crevices ask for a solution. For women of the previous centuries for instance, as the role of mothers and wives contradicted the asexuality from which their moral superiority derived, the solution had to be found through focusing the virginity discourse on the daughter. It was an inner fear. Like when we repeat in a Foucaultian way something trying to hide its opposite: «A vital Victorian mythology» dressed as Andersen's Mermaid, so different than L Inconnue de a Siene, that nature can't be institutionalised and that in a Freudian reverse «the fullness of woman's extraordinary and dangerous being might at any moment return through violence» (Auerbach,1982, p.8).

In the mid $20^{\text {th }}$ century it was like the revenge had finally arrive. If we think about it, the moment Plath listens a distant sea that di-privaticises her female bed connecting it with the foggy tides of a broader picture, Rich includes in her mourn the defeats of the clan. She has collective references, as the female subject was evolving from motherhood to citizenship. Interestingly psychoanalyst Judith Mitchell points (Mitchell, 2004) that in the period those poems written, during the $2^{\text {nd }}$ feminist wave, and parallel to poetry, the invented language of humanities, promoting terms like "gender" instead of women, was reflecting an unconscious turn towards sexual relations beyond child-bearing, and thus beyond motherhood. Death of motherhood in the 60's was not just a topic in some texts. Was an expression of broader evolutions, regardless if it was included in the texts.

\section{Literature}

But the grief taboo had mostly to do with the petit-bourgeoism of a white male world, being in a constant dialogue with the various perspectives of female world and in a stable contrast with subcultures like the afroamerican or other ethnic minorities literature. Constructed away from the cultural mainstream afroamerican tradition mourns: Slave narratives, sentimental novels, naturalist fictions, and novels of manners all supposedly confront and work through grief comparatively overtly, like Boker (ibid) assures. And not just that, but there are migration narratives of female displacement that focus on the traumatic aspects of death or even more loss (even of yourself).

But there exist a total reverse. We have in fact, along with death, a deep celebration of motherhood, and the importance of family; that are connected interestingly with the same causes the deterioration of family had in the white female world: With the quest for independence, personal dignity, and self-definition. Morrison and Angelou, representatives of the tremendous afroamerican tradition, both employ figures of mother and death to speak about collective tragedies: In her I Know Why the Caged Bird Sings, edited in the last year of the decade, consisting a kind of epilogue legacy, Angelou speaks about both death and rebirth of mother hood. Because Maya, the main heroine has been abandoned by both parents, thus mother too, and along with her bother must learn how to live without her. Living in the side of her aged momy, a replacement for her mother that carries the Memory of her clan, a textual symbol with tremendous importance concerning the liberation of minorities consciousness, Maya little by little illustrates how strength of character and a love of literature can help overcome racism and trauma by fulfilling the circle, as it ends when Maya becomes herself a mother at the age of 17 . In the course of Caged Bird, Maya transforms from a victim of racism with an inferiority complex into a self-possessed, dignified young woman capable of responding to prejudice. Motherhood helps Angelou to overcome the rape she had suffer as an eightyear-old child, a fact so silent that is presented briefly even in the text. Rape is used as a metaphor for the suffering of her 
race and gender. The book's title comes from a poem by African-American poet Paul Laurence Dunbar. The caged bird, a symbol for the chained slave, is an image Angelou uses throughout all her writings. But what is also caged and liberated is motherhood. A motherhood cancelled by abandonment and raoe and re-found, in fact re-invented by a young woman in the process of liberation. She becomes mother even by a "homophobic accident", but it's a motherhood not meant to stay in the existing roles and borders. The initial phrase of the caged birth cries out by herself. "What are you looking at me? I m not here to stay"

On the contrary Morrison speaks about the death as a maternal experience. In Darling, Mother looses daughter. Daughter comes back. Is death that haunts life. But it is a death that brings back of portion of life (the diseased child) into a life that carries a portion of death (the loss of the daughter). Possibly Morrison uses the daughter as a symbol of a future that was caged and murdered. Daughter, after all, has been murdered herself: 'As the physical embodiment of Sethe's murdered daughter, as well as those thousands who died during the middle passage' (Corey 37) therefore offers greater scope for interpretation. Beloved's return from the dead has the strongest effect on Sethe and Paul D. She '...awakens their emotions and memories, but she also arouses their fears' (Corey 39). In an evolving era like the 60's if Angelou goes back to the roots using momma, the grandmother, Morrison let the roots visit her, bringing though no liberation. 'Anything dead coming back to life hurts.' Writes, (Morrison 35) explaining the reluctant of the community to remember the Beloved, to remember a haunted collective memory. There is no hidden pledge to re-live like in Malherbe's poet. In those pages it is the dead that has also the worst of fates. But this mourn, this trauma it might acts as the tool to stand up and fight for liberation. $L$ Inconnue wants to be liberated by her death mask. And, similar to aspects of the white literature we examined, pain becomes the task, in fact the mean.

Even today when we speak or write about that era, we employ those symbolisms. In Park's Getting Mother's Body, in which Parks admits to being captivated by Faulkner's novel As I Lay Dying, a work told through multiple points of view, we have Billy Beede, whom in 1963, with the help of her friends and relatives, must travel to Arizona to exhume her mother's body before her burial site is destroyed by a new shopping center complex. In Faulkner's book, the mother speaks from her coffin; the same is true in Parks's novel, only in this instance, the mother, Willa Mae Beede, sings her thoughts since she had been a blues singer in life.

Travel back is not in fact to regain mother's body, but to rescue the "treasures" that had been buried with her: a pearl necklace and a diamond ring.. Gifts are under attack by the modernizing forces of the shopping center. The task overcomes pain. The task becomes the perseverance of it. And perseverance means the ability to touch. Not incidentally Irigaray and other theorists of French second wave feminism claim the importance of touch as a trademark of female sexuality, in opposition to male optic way. From that point of view this death of Mother brings forth the agony and the task to preserve a female lost heritage that at the end will remake (our) world, our cause sui.

\section{Conclusions}

Sixties's were a sunny decade. Despite clouds from Vietnam or Indochina, despite the growing social diversification, there was a general optimism that anything, almost anything, could happen. In France the heavy legacy of Europe was gaining new aspects, like a new world within. The second wave of Feminism was the outcome and the pick point of it all regarding women Denouncing women's enslavement to "motherhood", public figures like Beauvoir used radical language to remind that Eve should give birth to Eve first. In America, the "real" new world, the "American spirit", in a way and in some aspects, was evolving in the same masculine way the American Army was expanding in Vietnam. But American Adam had forgotten Eve. And Eve was political in an unpresented way, a wiser, in some perspectives, voice (in fact voices) that sensed the coming defeats. Mother and Death were used in the broader sense to remind the other side of bright living, the dark side of the moon. "Dying is an Art like all the others. I do it exceptionally well!" wrote Plath, expressing a collective voice of women, admitting she would transcend herself, or in fact transcend her alienation, her "other self". Interestingly "the Entire Western Civilization is founded upon the murder of the mother" wrote Irigaray $(1985,47)$. Male colonization evolved as cry or as silence. Not incidentally, when we speak about 60's we speak about the decades of the gothic romance. Apart from the Beloved, in the US, VIrginia Coffman, Phyllis Whitney and Barbara Michaels reigned. And as it was said '...the Gothic has functioned as a literary mechanism for the return of the repressed, anatomizing the pathologies lurking beneath the veneer of civilized modernity.'

In that sense motherhood could speak about alternative social values and death could speak about their losses. Literature had to express it once again: Whilst the image of the consumer was feminised and sentimentalised to be controlled in the 
postwar period, the power of the mermaid, dressed under various names and stories transcending life and death, and «always essentially feminine, escaped domestic control and threatened social order» (Auerbach, 1982).

Literature could still reveal the «darker forces» (Cox,1996,p.153) that were hidden «to Nation, the status and the honour». If women had played this part before, so powerfully represented for instance in the past in Caroll 's Alice, that "amalgamation of the fallen woman with the un-fallen child», the $60 ; s$ signaled a shift: the commonsensical border line between motherhood, (identified so far with life) and death was not that commonsensical anymore. In fact it could be controversial, questioning the disciplinary society, at the centre of which stood the nuclear family (Stone,1982, p.25), aiming to function projectively as «the lowest institution in the hierarchy of discipline» (Hill, 1964,p.443). This conflict between the motherhood and the family that second wave feminism brought created «a covenant theology» the most powerful seed of which was produced probably in France and the most famous literary fruits of which were probably "born" in USA. That "theology" cut Motherhood in two pieces: one expressed by maternal forgiveness (Laverenz,1980), the other by paternal severity, embodiment of the day of judgement itself. In the middle a new, "unreadable" woman tried to be born A woman that questioning motherhood's "need and fear" regained the quality to be un-fallen because she had chosen to deal and redefine in a new dark light her falls. 'A! I don't believe in sainthood unless she is born by the sin!" as Ritsos, a Greek poet wrote.

\section{References}

[1] Adorno Th, 2001 Minima Moralia, Athens Paratiritis.

[2] Angelou M. (1970) I Know Why a Caged Bird Sings, New York: Random House.

[3] Aggelaki Rourk K. 1985, Contemporary American poetry, trans. .Anatypo, Athens.

[4] Auerbach, N., 1982, «Woman and the Demon: The Life of a Victorian Myth», Cambridge, Harvard University Press.

[5] Bauman, Zigmund. Cultural Theory and Cultural Change: Survival as a social construct, in Featherstone, ed. «Cultural Theory and Cultural Change», pp 112- 126, London: Sage, 1992.

[6] Baudrillard, J.,1983, «Simulations», New York, Semiotext

[7] Beauvoir, S.,1972, The Second Sex, London, Penguin.

[8] Boker P. 1997, Grief Taboo in American Literature: Loss and Prolonged Adolescence in Twain, Melville, and Hemingway (Literature and Psychoanalysis, 8) New York University Press

[9] Brenkman, J. 1982. "The Other and the One: Psychoanalysis, Reading, The Symposium." Yale French Studies 55/56: 396-456.

[10] Buford N. (ed.) The Mother in/and French Literature, Rodopi, 2000.

[11] Campbell J. 1980, The Hero with a Thousand Faces, New York: Princeton University Press (Bollingen Series $\mathrm{XVII).}$

[12] Cassirer, Ernest. Language and Myth, Athens: Erasmos, 1989.

[13] Corey, G,.2008, Theory a d Practice of Counseling and Psychotherapy, Cencage Leaning

[14] Cox, Roger. Shaping Childhood, Themes of uncertainty in the history of adult-child relations, London: Routledge, 1996.

[15] Cunningham, H., 1991, "The Children of the Poor: Representations of Childhood Since the Seventeenth Century», Oxford, Blackwell.

[16] De Mause, L.,1976, «The history of childhood: The evolution of Parent-Child Relationships as a Factor in History», London, Souvenir Press.

[17] Fairclough, N.,1992, «Discourse and Social Change»,Cambridge, Polity.

[18] Fraser, A.,1989, «The weaker vessel: woman's lot in 19th century England», London, Mandarin.

[19] Foucault, M.,1984, «The History of Sexuality», Harmondsworth, Penguin

[20] Gorham (1978) reference in Cox,1996, p.151

[21] Grylls,1978 Grylls, D.,1978, «Guardians and Angels: Parents and Children in Nineteenth Century Literature», London, Faber and Faber.

[22] Hall, St. "Notes on Deconstructing the Popular". In People's History and Socialist Theory. London: Routledge. 1982.

[23] Heidegger, M. and Stambaugh J.(Translator), 1959, Identity and Difference. University of Chicago Press. June 2002. Paperback

[24] Hill, C., 1964, «Society and Puritanism in Pre- Revolutionary England», London, Secker and Warburg. 
[25] Irigaray, Luce, 1985, "The Power of Discourse and the Subordination of the Feminine" in Luce Irigaray, This Sex Which Is Not One, trans. Catherine Porter. Ithaca: Cornell University Press.

[26] Jenks, Ch.,1996, «Key Ideas: Childhood», London, Routledge.

[27] Kincaid, J. 1995, Autobiography of my Mother, Farrar Strauss and Giroux.

[28] Kline,1993, Kline, S.1993, "Out of the Garden: Toys, TV, and Children's Culture in the age of Marketing», London, Verso.

[29] Kristeva, Julia (1981), "Women Can Never Be Defined," in New French Feminisms, ed. Elaine Marks and Isabelle de Courtivron. New York: Schocken Books.

[30] Leverenz,1980, «The Language of the Puritan Feeling», N.J. Rutgers University Press.

[31] Lewis, R. W. B., 1955, The American Adam, Phoenix book New YorkRadcliff Brown, 1981, Ethics of Psycholanalysis, Athens Paratiritis

[32] Raymont, W. 1994. Culture and History. Athens : Gnosi.

[33] Lyotard, J.F. 1984, the Postmodern Condition, a report on knowledge, Minneapolis, University of Minnesota Press

[34] Mitchell, J., 2004, Women: The Longest Revolution: essays on feminism, literature and psychoanalysis. London: Virago; Pantheon Books U.S.A. (reprinted 1996, Vintage Reprints, USA).

[35] Page du Bois (1988), Sowing the Body: Psychoanalysis and Ancient Representations of Women. Chicago: University of Chicago Press

[36] Parker \& Pollock 1981, Old Mistresses Women and Ideology, New York, Pandora Press

[37] Peyre, A., 1961, Peguy sans Cocarde, Jose Millais Martin

[38] Pollock, G. 1999, Differencing the Canon. Routledge, London \& N.Y.,

[39] Rank, O. 1959, The Myth of the Birth of the Hero, and Other Writings, Philip Freund, Vintage Books. ed. New York

[40] Said, E. 1979, Orientalism: A Brief definition, New YorkVintage

[41] Schwartzman, H. B., Transformations: The Anthropology of Children's Play New York: Plenum Press, 1979.

[42] Sommerville, C.J., 1982, «The Rise and Fall of Childhood», Beverly Hills, Sage.

[43] Stehle, 1990, Language and Gender Interdisciplinary Percpectives.

[44] Skelton J. 2003, Death and dying in literature Advances in Psychiatric Treatment 9: 211-217 The Royal College of Psychiatrists

[45] Stone, L., «The rise of nuclear family in early modern England», in Rosenberg , C.E. The Family in History, Philadelphia, University of Pennsylvania Press, 1975.

[46] Webography

[47] www.enotes.com/twienth.century.criticism (1/9/2010)

[48] http://www.uv.es/fores/PoesiaUK2005/1Plath,\%20Sylvia/splath.htm Plath (14/3/2014)

[49] http://en.wikipedia.org/wiki/French_literature_of_the_20th_century (9/8/2012)

[50] www.suite101.com/content/gothic-a51536 (17/11/2013)

[51] http://poets.org/viewmedia.php/prmMID/15836 (8/9/2012) 